\title{
HPV E1/E2 Interaction Inhibitor Gel AP611074
}

National Cancer Institute

\section{Source}

National Cancer Institute. HPV E1/E2 Interaction Inhibitor Gel AP611074. NCI Thesaurus.

Code C100100.

A topical gel composed of a human papillomavirus (HPV) E1/E2 protein:protein

interaction (PPI) inhibitor with potential antiviral activity. Upon topical application of AP611074, this agent prevents binding of the HPV viral proteins E1 to E2, thereby preventing viral DNA replication and growth of HPV. This inhibits viral proliferation and may prevent the formation of anogenital warts caused by HPV. The HPV proteins E1 and E2 are essential for HPV viral replication. 